\title{
THE SIGNIFICANCE OF PSALM SINGING IN CALVIN'S LITURGY OF THE LORD'S SUPPER AND ITS RELEVANCE TODAY
}

\author{
Yudha Thianto \\ Trinity Christian College \\ Korespondensi:Yudha.Thianto@trnty.edu
}

\begin{abstract}
In this article, the author argues of the significance of Psalm singing in Calvin's Liturgy of the Lord's Supper. Metrical psalm singing is one of Calvin's contributions towards the changes in reformation worship. Furthermore, his emphasis on its use in the Liturgy of the Lord's Supper is an important retrieval from the wider diversity in many contemporary church worship. Throughout the article, the author endorses a creative use of psalm singing in the church. Such practice must not be forgotten that has been formative to the reformation in the past.
\end{abstract}

KEYWORDS: Psalm; Liturgy; Lord's Supper; Calvin.

\begin{abstract}
ABSTRAK: Di dalam artikel ini, penulis mengemukakan pentingnya menyanyikan mazmur di dalam liturgi Calvin saat perjamuan kudus. Menyanyikan mazmur metrikal adalah salah satu kontribusi Calvin terhadap perubahan di dalam ibadah pada masa reformasi. Terlebih lagi, penekanannya akan penggunaan Mazmur di dalam liturgi saat perjamuan kudus adalah upaya mengembalikan yang penting dari ibadah yang makin beragam di dalam banyak ibadah kontemporer. Di sepanjang artikel ini, penulis mendorong menyanyikan mazmur secara kreatif di dalam gereja. Praktek demikian tidak boleh dilupakan telah begitu berpengaruh terhadap reformasi di masa lampau.
\end{abstract}

KATA KUNCI: Mazmur; Liturgi; Perjamuan Kudus; Calvin. 


\section{Introduction}

One of the lasting impacts of Calvin's works in the church worldwide, beyond his theological teachings, is the tradition of the singing of the metrical psalm in the vernacular. Singing the psalms was Calvin's way of reforming the church from the very center of its worshiping experience. As such, Calvin made the efforts of changing people's mindset and understanding of what being a Christian meant by insisting that the entire congregation sing in the language that they understood, as an act of worship. He thought that there was nothing better than the psalms to express people's praises to God. ${ }^{1}$ This was a fundamental change compared to the way the people worshiped in the Medieval time before the Reformation. At that time, the center of the worshiping experience of the people was the Mass, the event when they received the body and the blood of Jesus in the sacrament. Other than the act of receiving the elements of the sacrament, the people did not have much participation in worship. The priest spoke in Latin, and the choir and chanting were also conducted in Latin, a language that common people did not understand. ${ }^{2}$

The Reformation changed the way the church brought worshiping experience. Luther's insistence that the Bible should be translated into the vernacular was an important first step to bring the Word of God to the people so that they can understand, internalize, and apply it in their lives. Singing hymns was the next step. Luther was also known as a composer. One of the most famous hymns that he penned was Ein Feste Burg ist unser Gott, or A Mighty Fortress is Our God in English. This is a hymn that most of us today know by heart and has been translated into many languages. We often sing it on Reformation Sunday. Calvin took the lead that Luther started and brought the singing experience into the church in Geneva where he did most of his works in reforming the church. However, instead of hymns, Calvin championed the singing of the psalms in metrical forms, in French, the language of most of the people living in Geneva. During the years of his ministry Calvin worked toward the publication of all 150 psalms and a small number of biblical songs set into certain tunes in the metrical form. Each of the psalms has particular meter. ${ }^{3}$

\footnotetext{
John Calvin, "Preface to the Genevan Psalter 1543, reprinted, in Les Pseaumes mis en rime francoise, by Clement Marot and Theodore de Beze (Geneva: De l'imprimerie de François Jaquy, pour Antoine Vincent, 1562), *iii recto.

2 Robert M. Kingdon, "The Genevan Revolution in Public Worship," Princeton Seminary Bulletin 20 (1999), 264.

3 John Witvliet, “The Spirituality of the Psalter: Metrical Psalms in Liturgy and Life in Calvin's Geneva," Calvin Theological Journal 32, no. 2 (Fall 1997): 273-97.
} 
The liturgy of the church in Geneva included the singing of the psalms and a handful of other songs that Calvin called ecclesiastical songs. As such, the singing of these psalms became an integral part of the whole liturgy. When the church celebrated the Lord's Supper the singing of the metrical psalm gained an even more significant place in the liturgy. This paper looks at how Calvin brought the singing of the metrical psalm in the liturgy of the church in Geneva, with a highlight of its significance in the liturgy of the Lord's Supper.

\section{Calvin and the Singing of the Metrical Psalms}

A metrical psalm is the versified form of the psalm in a particular meter or set number syllables in each line. The meter forms the main structure and rhythm of one particular poem. Most of us are familiar with the iambic pentameter. It is a line of a poem that has five sets of unstressed syllables followed by stressed ones. William Shakespeare is famous for his iambic pentameter sonnets. A metrical psalm works rather similarly. The psalms are rewritten into lines with specific meters, and each psalm is then set into certain tune. A good and perhaps the most famous example of a metrical psalm that originated in Calvin's Geneva is Psalm 98 that has been translated into English as "Sing, Sing a New Song to the Lord God." Here is the first stanza of this psalm:

Sing, sing a new song to the Lord God
for all the wonders he has wrought;
his right hand and his arm most holy
the victory to him have brought.
The Lord has shown his great salvation,
to Israel his love made known;
he has revealed to every nation
his truth in righteousness alone

In this metrical psalm, the first line has nine syllables, and the second line has eight. The pattern is repeated all the way down until the last line of the stanza. Then, when we look at the other stanzas of the psalm, the same pattern is used consistently. In this case we can say that this psalm has a meter of 9-8-9-8, double (or repeated).

Perhaps, the most famous tune out of the Genevan metrical psalms is the tune we use to sing the Doxology toward the end of our worship service. In Geneva, originally the tune was used for the versification of Psalm 134, composed by Louis Bourgeois in $1551 .{ }^{4}$ There are four lines in each stanza of the psalm, with each line having the meter of 8-8-8-8. The modern English

4 Christian Reformed Church (CRC), Psalter Hymnal, (Grand Rapids: CRC Publications, 1989), 134. 
translation of the first stanza of this psalm goes as follows: "You servants of the Lord, our God // who work and pray both day and night //in God's own house lift up your hands // and praise the Lord with all your might." The same meter also fits well for the Doxology: "Praise God from whom all blessings flow // Praise him all creatures here below // Praise him above ye heavn'ly host // Praise Father, Son, and Holy Ghost."

Even before he moved to Geneva, Calvin already expressed the importance of singing the psalms during church service. In the 1536 edition of the Institutes, when he discusses the celebration of the Lord's Supper, he emphasizes that the sacrament must be accompanied by the singing of a psalm or the reading of a Biblical passage. ${ }^{5}$ Similarly, when he was in Geneva for the first time, he drafted the Articles concerning the Organization of the Church and Worship. There he argued that the liturgy of the church must include the singing of the psalms. ${ }^{6}$

When he was in Strasbourg, he became more convinced about the place of the singing of the psalms at worship. His early work in versifying the psalms was highly influenced by Wolfgang Dachstein, the organist of St. Thomas church, and Matthias Greiter, the cantor of the same church. These two musicians were instrumental in assisting him toward the first step into writing some metrical psalms. The first psalm that he set to music was Psalm 46. He employed the tune written by Dachstein that the latter used for the versification of Psalm 25 in German. He used some of the melodies composed by Greiter for the French metrical psalms that he arranged. In Strasbourg he also worked toward setting the Song of Simeon, the Ten Commandments, and the Apostles' Creed into versified forms to be sung at church. His interactions with Clement Marot helped move forward the work of composing the metrical psalms. In 1539 Calvin published the psalms of Clement Marot and his own compositions in a small psalter. ${ }^{7}$

In the church order of Geneva published in 1541 after he came to Geneva for the second time, Calvin included an article about singing: "It will be desirable to introduce ecclesiastical songs in order the better to incite the people to prayer and to the praise of God. To begin with, the little children shall be taught, and then in course of time the whole church will be able to follow." ${ }^{8}$ What Calvin means by "ecclesiastical songs" in this case is the metrical psalms. Calvin has keen eyes on empowering children to

\footnotetext{
John Calvin, Institutes of the Christian Religion 1536 (Grand Rapids: Eerdmans)

Daniel Trocmé-Latter, "The Psalms as a Mark of Protestantism: The Introduction of Liturgical Psalm-singing in Geneva," Plainsong and Medieval Music 20, no. 2 (2011);145-63.

John Calvin, Aulcuns pseaulmes et cantiques mys en chant, (Strassburg, 1539).

8 The Church of Geneva, "Ecclesiastical Ordinances 1541," in Philip E. Hughes, The Registers of the Company of Pastors in Geneva at the Time of Calvin, (Grand Rapids: Eerdmans, 1966), p. 45
} 
lead in singing, because children can easily catch a tune. They like singing wherever they are, at home, while playing, on a trip, and in just about any activity. When the children learn the psalms, first of all, they will internalize the message of the psalms and they will grow up with the teaching of the scripture. Secondly, children can help the adults in the community learn the canticles better. Therefore, the strategy of teaching the children first is very appropriate.

Calvin equalized singing at church to praying. In the preface to the publication of the psalter in 1543 that he wrote on June 10, 1543, he explicitly mentioned that we can sing in two ways, first through words as we regularly pray, and secondly through our songs. In his opinion, singing can move our hearts deeply so that through songs we praise God and adore him dearly. ${ }^{9}$ He also reminded people that the songs we choose to sing to God must be so selected that they are always God-honoring and not just for the entertainment of ourselves as human beings. We must distinguish between songs that we sing at dinners or other social events and those we sing at church in the presence of God and his angels. Singing at church also has the function of edifying the people in the truth of God's words. ${ }^{10}$

God has created our bodies so beautifully, and the tongues are specially created to speak and sing praises to God. In the Institutes Calvin writes that when people sing together at church, they must sing with one voice as though they sing with just one mouth, to worship God in one spirit and in one faith. ${ }^{11}$ Based on this view, he insisted that the church in Geneva sang only in unison, without any musical accompaniment. He strongly states that's when we sing our minds must only focus on the words we say to God, and the melody of the song should not distract us from the words we say to God. ${ }^{12}$ Singing in harmony, in his opinion, is a distraction and therefore should be prohibited in the context of worship.

Calvin did not allow the use of musical instruments in church. He thought that the use of music in worship only belonged to the Old Testament people. He thought that musical instruments were needed by the people in the biblical time but is no longer necessary for the people today. ${ }^{13}$ The tunes used for the metrical psalms were taken from melodies that the people were already familiar with. Therefore, when Calvin adopted the style for

\footnotetext{
Calvin, "Preface to the Genevan Psalter 1543."

10 John Calvin, Institutes of the Christian Religion 1559, ed. John T. McNeill (Philadelphia: Westminster Press, 1960), 3. 20. 31

11 Calvin, Institutes, 3. 20. 31

12 Calvin, Institutes, 3. 20.32.

13 John Calvin, Commentary on the Book of Psalms, vol. 2 trans. James Anderson (Grand Rapids: Eerdmans, 1949), Psalms 81:3
} 
the metrical psalms, these folk tunes had some influence in the tradition of singing the psalms in the church. However, we must also take into consideration that the tunes of the Genevan psalms were influenced by the chanting tradition of the Medieval church. ${ }^{14}$

The tunes of the psalms are modals. They follow the ancient Greek modes of music writing. In the Medieval time the Greek modes underwent significant evolution, improvements, and modifications. Around the eleventh century they reached the final form. There are six modes in the modal system. The naming of each mode depends on how the canticle ends. The modes are differentiated based on the last or finalis position of the whole tones or semitones of the diatonic octave. In a canticle or a song, the finalis note is the last one to be sung. The six modes are named: Ionian, Dorian, Phrygian, Lydian, Mixolydian, and Aeolian..$^{15}$ When we compare these modes to the modern, diatonic scale we are accustomed to singing from $\mathrm{C}$ to $C$ today, the Ionian mode runs from $C$ to $C$ and is called to have the tonica or finalis do. The Ionian forms the most stable pitch and sounds similar to our modern major scale. The Dorian mode runs from $\mathrm{D}$ to $\mathrm{D}$ and therefore is said to have the tonica or finalis re, the Phrygian is from E to E (tonica or finalis $\mathrm{mi}$ ), the Lydian runs from $\mathrm{F}$ to $\mathrm{F}$ (tonica or finalis fa), the Mixolydian runs from $\mathrm{G}$ to $\mathrm{G}$ (tonica or finalis sol), and the Aeolian from A to A (tonica or finalis la). The Aeolian mode is very similar to the modern minor scale that we sing today.

The psalter that the church in Geneva published in 1543 has forty-nine psalms, mostly written by Clement Marot. ${ }^{16}$ This psalter includes thirty psalms that Marot had published elsewhere before and some new psalms. It also has the versified forms of the Song of Simeon, the Ten Commandments, the Apostles' Creed, the Lord's Prayer, and the song of the angels. The psalter also has prayers for before and after meals to be used by the people at home.

Theodore Beza, Calvin's younger colleague and successor in Geneva, also had the gift of versifying the psalms. After Marot died Beza continued the work in expanding the compositions of the metrical psalms in French, with the goal that all 150 psalms would eventually be written in the metrical forms and assigned particular tunes so that the church could sing all the 150 psalms. Louis Bourgeois came to Geneva to work as a cantor in 1542. He was also paid to write melodies for the psalms to add to the ones that were

14 Louis F. Benson, John Calvin and the Psalmody of the Reformed Churches, delivered on the L. P. Stone Foundation, at Princeton Theological Seminary, in February 1907.

15 Jane P. Clendinning and Elizabeth W. Marvin, eds., The Musician's Guide to Theory and Analysis, 3rd ed. (New York: Norton, 2016), 104.

16 L'eglise de Geneve, Cinquante pseaumes en françoys par Clement Marot, (Geneva, 1543). 
already composed and published. ${ }^{17}$ In 1551 the Genevan church published a new psalter, Pseaumes octante trois de David. This psalter has thirty-five tunes that were composed by Bourgeois and some texts written by Theodore Beza. In 1554, the same work was reprinted and expanded with some new, additional texts versified by Beza. Finally, in 1562, only two years before Calvin died, the church of Geneva was able to publish a psalter of all the 150 psalms, Les Pseaumes mis en rime française, par Clement Marot, et Theodore de Beze. It also has two additional canticles, namely the Song of Simeon and the versified form of the Ten Commandments. There are 125 tunes used for the 150 psalms in the edition. ${ }^{18}$ This means that there were some tunes that are used for multiple psalm texts. Bourgoeis left Geneva for Lyons and then he moved to Paris because he had some sharp disagreements with the Genevan city council. He wrote four-part harmony for all the psalm tunes that Geneva published.

When we look at the texts of the metrical psalms, we see that they are not strictly taken from the words of the Bible. They are the result of the poets' rewriting of the biblical psalms into poems with each individual meter. Before he wrote the metrical psalms Marot wrote poems for the French court. His experience was influential in the direction of the versification of the psalms to be sung in Geneva. The versifications of the psalm had to take be done in such a way that they verses could be sung with ease when they were set into their tunes. Marot, Beza and other poets who worked on the versifications of the psalms had to work very hard to ensure that the words of the psalms in the Bible are accurately turned into the metrical psalms, while at the same time they had to make the psalms as singable as possible. ${ }^{19}$

The 1562 edition of the Genevan Psalter was very popular during Calvin's lifetime. It is estimated that there were 27,000 copies of the psalter printed and distributed. Within a few years the total copy of the psalter printed and sold exceeded 100,000 copies. Soon afterwards the psalms were translated into several European languages. This is a good indicator that singing the metrical psalms became a marker of being Protestants in Europe in the latter part of the sixteenth century. Protestants in Europe formed an identity by way of singing the psalms. ${ }^{20}$

17 Witvliet, "The Spirituality of the Psalter," 283.

18 L'Eglise de Geneve, Les pseaumes mis en rime française, par Clement Marot, et Theodore de Beze (Geneva, 1562).

19 Witvliet, "The Spirituality of the Psalter," 284.

20 Witvliet, "The Spirituality of the Psalter," 284. 


\section{The Metrical Psalms in the Liturgy of the Church in Geneva}

In 1542 the church of Geneva published a small booklet that regulates worship in the church with the title La Forme des prieres et chantz ecclesiastiques, avec la manière d'administrer les sacraments. In this booklet he included thirty-nine metrical psalms, mostly composed by Clement Marot. Even though Calvin's name was not explicitly mentioned as the author of this small booklet, scholars agree that Calvin was indeed the one writing it. ${ }^{21}$ In the La Forme des prieres the Apostles' Creed is written as a text. In the letter to the readers that accompanied the booklet, Calvin reminds his congregation that the three most important elements in worship are prayer, sermon, and the sacraments. As it is his strong belief all along, he states that praying includes singing. ${ }^{22}$ Calvin also emphasizes that over against the practice of the church in Rome, congregation singing must be conducted in French, the language of the people. ${ }^{23}$ God has given the people music, and therefore music must be used appropriately in worship to glorify God.

The liturgy for Sunday worship written in the booklet starts with the minister making the invocation, quoting from Psalm 121, saying "Our help is in the name of God, creator of heaven and earth. Amen." Then, the minister leads the people in confessing their sins, followed by the reading of a particular Bible passage that gives the assurance of pardon for the people. ${ }^{24} \mathrm{After}$ the assurance of pardon the whole congregation sings a psalm. ${ }^{25}$ When the La Forme des prieres was revised in 1545, the new liturgy added the singing of the first table of the Ten Commandments after the singing of the psalm. The singing of the psalm is then followed by a prayer. Another psalm singing follows the prayer. In the 1545 revision of the liturgy, the psalm singing is followed by the singing of the second table of the Ten Commandments. At this point the minister will leave his chair and goes up to the pulpit to get ready to deliver the sermon. Once the minister is at the pulpit, he will lead a prayer that is ended with the Lord's Prayer. Another singing of the psalm comes in between the Lord's Prayer and the prayer for illumination in which the minister invites the Holy Spirit to illumine the hearts and minds of the people so that they can understand the meaning of the word of God that will be preached, and that the word of God will be spoken by the minister for the glory of God's name alone. The reading of the scripture and the delivery of the sermon go one after another after the prayer of illumination.

\footnotetext{
L'Eglise the Geneve, La Forme des prières et chantz ecclesiastiques (Geneva, 1542).

La Forme des prières, a 4 recto

La Forme des prières, a 3 verso

La Forme des prières, i6 recto.

La Forme des prières, i6 verso
} 
The sermon concludes with a prayer that includes the intercessory prayer for God's people. ${ }^{26}$ Before the service ends, the minister provides a reasonably long explanation of the meaning of the Lord's Prayer, a singing of a psalm, and the parting blessing from Numbers chapter 6 .

\section{Singing the Psalms in Calvin's Liturgy of the Lord's Supper}

When we look at the liturgy carefully, you can see that in one Sunday service, the congregation sang four psalms. And then, when the liturgy was revised in 1545, they also sang the Ten Commandments regularly. When the church celebrated the Lord's Supper, the liturgy added the singing of another psalm during the distribution of the bread and the wine. The 1545 liturgy also added the singing of the Song of Simeon after the celebration of the Lord's Supper. All of these made the singing experience of the people at church a significant presence in their spiritual life. This was a significant step that Calvin introduced in reforming the church in Geneva. The singing of the psalms in French, besides functioning as the prayer of the people as Calvin often emphasized, helped the people to be more well-versed in God's words, especially that written in the Book of Psalms. By singing regularly in the language that they knew, the people built their knowledge of the Bible and their spirituality one canticle at a time. This slow but deliberate effort to build the Christian experience of the people was a very important work to ensure that the people grow in their faith. This was a stark contrast to the way the Medieval church operated before the Reformation. In the time before the big changes happened, the church only used Latin, and the congregation did not receive spiritual nurture through the words of the Scripture in a language that they could understand. As singing involves both the artistic and intellectual sides of a human being, it expands the person's life as a whole. Singing the psalm can advance the work of the Reformation at the most fundamental level in the personal experience of each individual. In Calvin's Geneva, all of the people sang together. This included men, children, and women. The inclusion of women in singing was another important progress in the Protestant church. Before the Reformation, women's singing voices were only heard in convents when the nuns sang. But in the Protestant church after the Reformation, women's voices were literally heard in church as they sang together.

While Calvin's liturgy of the Sunday service and also the liturgy of the Lord's Supper still carried some elements of the Medieval Mass, there was also a striking contrast between the two. One very obvious difference

26 La Forme des prières, $\mathrm{k} 2$ verso 
is the language. The Mass used Latin thoroughly, ${ }^{27}$ whereas Calvin's liturgy was in French. Another point of difference is the lack of the congregation's participation in the Mass. In Calvin's liturgy, the singing of the psalms, the Ten Commandments, and the Song of Simeon marked the active participation of the congregation. This was a significant change in the Reformed church. As it was always Calvin's strong position, singing in church equals to praying. Therefore, when the congregation sings during church service, they also pray. Calvin saw that singing the psalms in worship the most fitting because the words of the psalms come directly from God.

In the liturgy of the Medieval Mass, after the priest raised the chalice and the host (or bread) and prayed, he would then replace the elements back on the altar, then he either chanted or spoke: "Per omnia saecula saeculorum. Amen." 28 During the ceremony, this was the only time the congregation heard a chanting before they received the Communion. As the people received the host, there was no singing or chanting happening. Instead, the priest would say to each person receiving the host: "Corpus Domini nostril Jesu Christi, custodiat animamtuam in vitam aeternam. Amen." ${ }^{\prime 2}$ The next time the congregation heard another chant, if the priest decided to do it instead of just saying the words, was after the priest drank the wine, the subdeacon (or the priest himself) wiped the chalice dry and veiled it. He would chant: "Dominus vobiscum," to which the congregation responded: "Et cum spiritu tuo." ${ }^{\prime \prime 0}$

In the Genevan liturgy, Calvin added the singing of some psalms when the bread and wine were distributed. ${ }^{31}$ This addition is very important for us to understand. It makes a big contrast between the Medieval Mass and the Genevan liturgy of the Lord's Supper. The singing of the psalms further signifies Calvin's theological insistence of the oneness between the sacrament and the Word of God. For Calvin they are inseparable. Therefore, it is fitting that the singing of the psalms accompanied the distribution of the bread and wine. As the people receive the elements of the Lord's Supper, they sing some metrical psalms, so as to proclaim the Word of God as they partake in the sacrament.

27 See, "Canon of the Mass," in Bard Thompson, ed., Liturgies of the Western Church, (New York: Meridian Books, 1970), 72-89.

28 This means: "World without end. Amen." See, "Canon of the Mass," 77.

29 This means: "The Body of our Lord Jesus Christ preserve your soul for everlasting life." See, "Canon of the Mass," 85.

30 They mean: "The Lord be with you," and "And also with your spirit." See, "Canon of the Mass," 87.

31 Calvini Opera VI, p. 199. 
Another important singing experience in the liturgy of the church in Geneva was the inclusion of the versified Song of Simeon at the end of the liturgy of the Lord's Supper. ${ }^{32}$ Even though the Song of Simeon is not in the Book of Psalms, but written in the Gospel of Luke chapter 2, this song or canticle has always been an important part of the Genevan church's repertoire. Calvin included a handful songs that are biblical but not from the Book of Psalms in the Genevan psalter. These include the versifications of the Lord's Prayer, the Apostles' Creed, the Ten Commandments, and the Song of Simeon. ${ }^{33}$ These canticles or songs, written in French in the metrical form, had the role of teaching the people the foundation of the Christian faith. Together with the versified psalms they built the corpus of the singing tradition in the church in Geneva.

The Song of Simeon occupies a strategic role in ending the liturgy of the Lord's Supper. It functions as the song of response of the people after they receive the sacrament, and before they are sent out with a parting blessing based on Number $6 .{ }^{34}$ In English, the lyrics of the first stanza says: "Now may your servant, Lord // according to your word, // depart in exultation. // My peace shall be serene // for now my eyes have seen // your wonderful salvation." ${ }^{35}$ The meter of this canticle is 6-6-7-6-6-7, and the tune was composed by Louis Bourgeois. Just as Simeon in Luke 2 received the baby Jesus and was delighted to see the wonderful salvation that God has provided for his people, Christians are also called to embrace the salvation from the Lord. The Lord's Supper is a clear demonstration of how God has saved his people. Jesus has come to complete the work of redemption. Therefore, the people can now go into the world and serve God in their lives.

\section{How Singing the Psalms is Still Relevant Today}

In modern day Christianity, very rarely have we experienced the singing of the psalms as a regular part of the liturgy, both the liturgy of services in general, and the liturgy of the Lord's Supper in particular. There are some hymns and Christian songs that are rooted in particular psalms, but the majority of us have lost the constant experience of singing the psalms themselves. When I was growing up in Semarang, Indonesia, my church sang from the psalter hymnal called Mazmur dan Nyanyian Rohani, a collection of all the 150 psalms from the Genevan psalter and 200 hymns. ${ }^{36}$ While

32 Calvini Opera VI, p. 200. See also Thompson, Liturgies, p. 208.

33 L'Eglise the Geneve, La Forme des Prieres, h8 recto - i5 recto.

34 L'Eglise the Geneve, La Forme des Prieres, k4 recto.

35 CRC, Psalter Hymnal, p. 216.

36 Taman Pustaka Kristen, Mazmur dan Nyanyian Rohani: Dari Perbendaharaan Jemaat Segala Abad, Indonesian translation by I. S. Kijne, (Jakarta: BPK Gunung Mulia, 1997). 
it is still available in some Christian bookstores in Indonesia, I do not see it being used by churches that I know. I find that the church is missing something important by this departure from singing directly from the psalms.

While we do not have to stand thoroughly and fully with Calvin in all that he insisted regarding church singing, most notably his view that we should not sing in harmony without musical accompaniment, I still want to emphasize the need for the singing of the psalms in church. I fully agree with him that singing in church is another form of prayer, and that when we sing, we actually pray. Therefore, for Calvin, our songs matter. The words of our songs should be the words that we would bring to God in our prayers. And I also agree with Calvin that God has provided us with the best songs we can ever sing to him, namely the Book of Psalms. But in today's church I also think that we can expand this a little bit further.

Church singing should be adapted into the cultural contexts of the ones singing. We can still adapt the singing of the psalms into our context in the modern world today. One effort that I see as having a significant impact is the publication of a modern psalter called Psalms for All Seasons: A Complete Psalter for Worship. ${ }^{37}$ This modern psalter is a collection of all 150 biblical psalms in variety of musical settings. The editors of this psalter gather as many forms and styles from as many languages there are for each psalm that they can get a hold on. For each numbered psalm there are about five or six settings or arrangements. Therefore, churches can choose the style or form of the psalm that fits their overall worship style and liturgy and bring back the experience of psalm singing for the congregation. This psalter can bridge the need for churches all over the world to sing the psalms, without necessarily having to sing only the Genevan tunes of the psalms.

Learning from the singing of the psalms in Calvin's liturgy of the church in Geneva, I would like to invite all of us today to think about including the singing of the psalms when we celebrate the Lord's Supper in our churches. We can be creative in selecting which style or setting of the psalms we choose to fit the overall liturgical structure of our particular church, but the key is that we bring our congregation to sing the psalms. There is richness in singing the psalms. As there are many kinds of psalms we have in the Bible, including psalm of praise, lament, thanksgiving, and the like, we can select particular psalm that can go together with the whole liturgy. That way we help our congregation to experience this singing tradition, as we also learn from the practice that Calvin brought in the church in Geneva.

37 Calvin Institutes for Christian Worship, Psalms for All Seasons: A Complete Psalter for Worship, (Grand Rapids: Brazos Press). 


\section{Conclusion}

While we do not have to follow all practices that Calvin did in the church in Geneva in the sixteenth century, we can still keep the spirit of reforming the church through singing the psalms that Calvin expanded during his lifetime. Being Reformed or Calvinist does not need to mean doing everything Calvin did. For instance, Calvin had his own reasons to prohibit people from using musical instruments and singing in harmony during worship services. Today, we are free to use musical instruments and to sing in harmony in our churches. The liturgy of our worship, be it the one for regular church services or that of the Lord's Supper, should be rooted in the beliefs and practices of historic Christianity, but must also be adapted to our own context. Singing in Bahasa Indonesia or in any other language that we speak stands together with Calvin's view of singing in worship. And singing psalms, hymns, or church songs in the musical style of our time and culture, too, is in line with what Calvin practiced. After all, the tunes and the melodies used in Geneva were the ones that the people in that time were familiar with.

One important lesson that we can bring for our liturgy today is to bring back the singing of the psalms as much as possible into the worship experience of our congregation. Just as Calvin pointed out long ago, the Book of Psalms is the book of songs and prayers of the people. We need to bring this back to the pews. Let us guide and teach our congregations to see the depth of the biblical psalms through songs that are composed based on or directly taken from all the 150 psalms that we have.

\section{References}

Benson, Louis F. John Calvin and the Psalmody of the Reformed Churches, delivered on the L. P. Stone Foundation, at Princeton Theological Seminary, in February 1907.

Calvin, John. Institutes of the Christian Religion 1536. Grand Rapids: Eerdmans. . Aulcuns pseaulmes et cantiques mys en chant. Strassburg, 1539.

. "Preface to the Genevan Psalter 1543, reprinted, in Les Pseaumes mis en rime francoise, by Clement Marot and Theodore de Beze. Geneva: De l'imprimerie de François Jaquy, pour Antoine Vincent, 1562.

. Institutes of the Christian Religion 1559, ed. John T. McNeill. Philadelphia: Westminster Press, 1960.

. Commentary on the Book of Psalms, vol. 2 trans. James Anderson. Grand Rapids: Eerdmans, 1949.

Calvin Institutes for Christian Worship, Psalms for All Seasons: A Complete Psalter for Worship, (Grand Rapids: Brazos Press). 
Christian Reformed Church (CRC), Psalter Hymnal. Grand Rapids: CRC Publications, 1989.

Clendinning, Jane P. and Elizabeth W. Marvin, ed. The Musician's Guide to Theory and Analysis, 3rd ed. New York: Norton, 2016.

Hughes, Philip E. The Registers of the Company of Pastors in Geneva at the Time of Calvin. Grand Rapids: Eerdmans, 1966.

Thompson, Bard, ed. Liturgies of the Western Church. New York: Meridian Books, 1970.

Trocmé-Latter, Daniel. "The Psalms as a Mark of Protestantism: The Introduction of Liturgical Psalm-singing in Geneva." Plainsong and Medieval Music 20, no. 2 (2011): 145-63.

Kingdon, Robert M. “The Genevan Revolution in Public Worship." Princeton Seminary Bulletin 20 (1999).

Witvliet, John. "The Spirituality of the Psalter: Metrical Psalms in Liturgy and Life in Calvin's Geneva." Calvin Theological Journal 32, no. 2 (Fall 1997): 273-97.

L'Eglise the Geneve, La Forme des prières et chantz ecclesiastiques. Geneva, 1542. L'eglise de Geneve, Cinquante pseaumes en françoys par Clement Marot. Geneva, 1543.

L'Eglise de Geneve, Les pseaumes mis en rime française, par Clement Marot, et Theodore de Beze. Geneva, 1562.

Taman Pustaka Kristen, Mazmur dan Nyanyian Rohani: Dari Perbendaharaan Jemaat Segala Abad, Indonesian translation by I. S. Kijne. Jakarta: BPK Gunung Mulia, 1997. 